\title{
Coaching as a strategy for the health promotion of the elderly: a systematic review
}

Abstract

Objective: To evaluate the effect of the application of coaching on the health promotion of the elderly. Method: A systematic review was performed in the PubMed, MEDLINE and SciELO databases. The selection of articles followed the PRISMA guidelines, and the articles were published from 2008 to July 2018. The following descriptors were used: aged (idoso, anciano), elderly (idoso, anciano), coaching (tutoria, tutoría), mentoring (tutoria, tutoría) and health promotion (promoção da saúde, promoción de la salud). Boolean operators were used for all databases: (coaching OR mentoring) AND (health promotion) AND (aged OR elderly); (idoso) AND (tutoria OR coaching) AND (promoção da saúde); (anciano) AND (tutoría OR coaching) AND (promoción de la salud). Results: The final analysis included three articles. These evaluated coaching tools for changes in lifestyle and the reduction of health risks for the elderly. The results were positive, with a significant improvement in the quality of life (mental and physical), health status, goal attainment, self-efficacy and increased immunization of the evaluated elderly persons. Conclusion: The use of coaching in health promotion in elderly is still incipient, however, based on the results, health coaching proved to be an effective strategy to enable the elderly to reach the maximum potential of self-management in health.

\footnotetext{
Centro Universitário de Maringá (UNICESUMAR), Programa de Pós-graduação em Promoção da Saúde, Mestrado em Promoção da Saúde. Maringá, PR, Brasil.

2 Universidade Estadual de Maringá (UEM), Departamento de Estatística (DES), Programa de Pósgraduação em Bioestatística. Maringá, PR, Brasil.

3 Centro Universitário de Maringá (UNICESUMAR), Programa de Pós-graduação em Promoção da Saúde, Produtividade em Pesquisa do Instituto Cesumar de Ciência, Tecnologia e Inovação (ICETI). Maringá, PR, Brasil.
}

\author{
Graciele Reinert Casadei' ${ }^{\mathbb{D}}$ \\ Eraldo Schunk Silva² ${ }^{\mathbb{D}}$ \\ Leonardo Pestillo de Oliveira ${ }^{3}$ iD \\ Rose Mari Bennemann ${ }^{3}$ (D)
}

Keywords: Health of the Elderly. Coaching. Health Promotion. Quality of Life.

The authors declare that there are no conflicts of interest in relation to this study.

No funding was provided for this study.

Correspondence

Graciele Reinert Casadei

gracielerei@hotmail.com

Received: March 29, 2019 Approved: September 09, 2019 


\section{INTRODUCTION}

Coaching is an important strategy for encouraging personal development, and is a major driving force of responsibility, organization, quality of care, support and the affirmation of human potential. Its essence is the development of skills to achieve goals. Thus, coaching contributes to the sustainability of an organization and the growth of the individual, allowing managers to realize that constructive and proactive change generates emotionally intelligent leaders who seek improvement and the ability to overcome problems, promoting productivity and, consequently, quality of life ${ }^{1}$.

The development of coaching has been exponential around the world, with the emergence of diverse schools, various lines of thought, different views, approaches and applications for varied markets and publics ${ }^{2}$. One of the modalities of coaching is health coaching, which is a health intervention aimed at helping the individual to set goals that promote health, such as changes in behavior and lifestyle to reduce health risks and improve quality of life ${ }^{3}$. In other words, health coaching helps patients find the motivation to initiate and maintain change by offering a variety of perspectives, and the recognition that various factors contribute to achieving goals ${ }^{4}$.

Some studies ${ }^{5-7}$ that have evaluated health coaching identified positive results regarding behavior and lifestyle changes such as increased physical activity, improved nutrition and the improved management of chronic diseases.

Each year nearly 58 million individuals reach the age of 60 , so the aging of the world's population cannot be ignored, as it poses challenges to public health, particularly in health promotion ${ }^{8}$. The postponement of chronic illness and the effective management of existing diseases and disabilities among the elderly are important if a positive impact on the quality of life of this age group is to be achieved.

Based on the above, the present study aimed to evaluate, through a systematic review, the effect of the application of coaching on health promotion in older individuals.

\section{METHOD}

The selection of articles included in this systematic review followed the guidelines of the Preferred Reporting Items for Systematic Reviews and MetaAnalyzes (PRISMA) 9 . The guiding question for the search was: What effect does coaching have on the bealth promotion of the elderly?

The PubMed database of the National Library of Medicine, Medical Literature Analysis and Retrieval System Online (MEDLINE) and the Scientific Electronic Library Online (SciELO) were used for the article search, which was carried out in July 2018, seeking articles published in Portuguese, Spanish and English between 2008 and July 2018. The Health Science Descriptors(or DeCS) were used, together with their equivalents in English from the Medical Subject Headings - MeSH list: aged (idoso, anciano); elderly (idoso, anciano); coaching (tutoria, tutoría); mentoring (tutoria, tutoria) and health promotion (promoção da saúde, promoción de la salud). Boolean operators were applied in all the databases: (coaching OR mentoring) AND (health promotion) AND (aged OR elderly); (idoso) AND (tutoria OR coaching) AND (promoção da saúde) and (anciano) AND (tutoria OR coaching) AND (promoción de la salud).

As eligibility criteria the review included articles that were available free and in full; which employed health coaching, regardless of the tool and delivery method (in person, by telephone or via the internet); conducted with older adults (age $\geq 60$ years); and which evaluated the effect of the application of coaching on the promotion of health among the elderly. Duplicate articles were excluded, as well as those unavailable online; abstracts and reviews.

For the selection and evaluation of articles, an instrument was developed containing the following variables: authorship; year; country of publication; type of study; number of participants; age range; statistic; intervention period; objectives; type of coaching delivery; coaching tool used and results achieved. 
Four phases were selected for article selection: 1) identification of articles in the databases; 2) screening for inclusion and exclusion of studies by reading of the titles and abstracts; 3 ) full reading of the selected articles; 4) final selection of articles that met the systematic review eligibility criteria.

The articles identified by the search strategy were independently evaluated by two researchers.

\section{RESULTS}

The search resulted in 317 publications, 178 (56.2\%) in PubMED, 139 (43.8\%) in MEDLINE and zero $(0 \%)$ in SciELO. From the titles and abstracts of the articles, 42 articles met the eligibility criteria, of which 21 were removed as they were duplicates, i.e. articles found in the MEDLINE database were also indexed in PubMED (Figure 1).
After reading the full texts of the 21 pre-selected articles, 18 studies were excluded: ten for including participants under 60 years of age, six for describing future or ongoing research protocols and two which did not fully address the objectives of the review (Table 1). In the end, three studies met the eligibility criteria and comprised the results of this review (Chart 2) years.

Chart 2 describes the articles selected and included in the review. The selected articles were published in years $2016(n=1)$ and $2017(n=2)$. The countries in which the surveys were conducted were: the Netherlands, South Korea, and the USA. The average age of the older adults ranged from 64.7 to 80.9 years. The studies were developed as randomized controlled trials, with the presence of intervention and control groups. The number of participants ranged from 90 to 18,107. The $t$ and Chi-square tests were mainly used for statistical analysis.

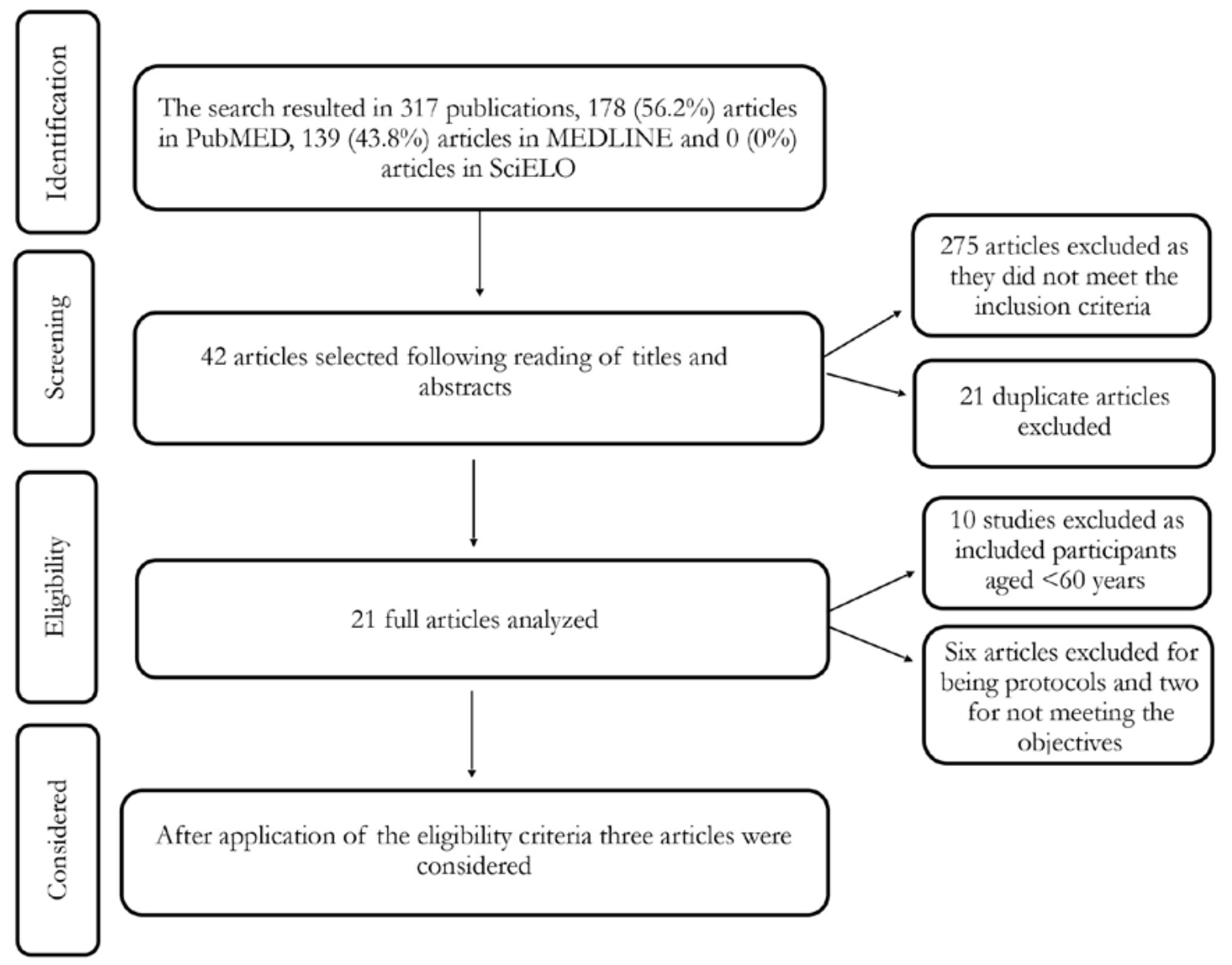

Figure 1. Flowchart of article selection. Maringá, Paraná, 2018. 
Chart 1. Description of pre-selected articles subsequently excluded from the review. Maringá, Paraná, 2018.

\begin{tabular}{|c|c|c|c|}
\hline $\begin{array}{l}\text { Author, year, country } \\
\text { of publication }\end{array}$ & $\begin{array}{l}\text { Number of participants, age } \\
\text { group, delivery method }\end{array}$ & Intervention period, objectives & Exclusion, reason \\
\hline $\begin{array}{l}\text { Clark et al., 2011, } \\
\text { USA }^{10}\end{array}$ & $\begin{array}{l}\mathrm{N}=470 \\
\text { Patients } \geq 65 \text { years } \\
\text { Telephone coaching }\end{array}$ & $\begin{array}{l}\text { Intervention: } 48 \text { months. } \\
\text { Evaluate an intervention } \\
\text { (SENIOR II Project) to } \\
\text { promote the maintenance of } \\
\text { both exercise and healthy eating } \\
\text { in the elderly. }\end{array}$ & $\begin{array}{l}\text { Article removed from } \\
\text { review as described } \\
\text { in progress or future } \\
\text { research protocol. }\end{array}$ \\
\hline $\begin{array}{l}\text { Long et al., 2012, } \\
\text { USA }^{11}\end{array}$ & $\begin{array}{l}\text { Group 1: control } \\
n=39 ; 60( \pm 4) \text { years } \\
\text { Group 2: telephone monitoring } \\
n=39 ; 60( \pm 5) \text { years } \\
\text { Group 3: financial intervention } \\
n=40 ; 59( \pm 5) \text { years } \\
\text { Telephone coaching }\end{array}$ & $\begin{array}{l}\text { Intervention: six months. } \\
\text { Assess whether mentors or } \\
\text { financial incentives help African } \\
\text { American veterans improve } \\
\text { their glycated hemoglobin } \\
\text { (HbA1c) levels. }\end{array}$ & $\begin{array}{l}\text { Article removed from } \\
\text { review as included } \\
\text { participants aged } \\
\text { younger than } 60 \text { years. }\end{array}$ \\
\hline $\begin{array}{l}\text { Patja et al., 2012, } \\
\text { Finland }^{12}\end{array}$ & $\begin{array}{l}\text { DM2 } \\
\text { Intervention group: } \mathrm{n}=770 ; \\
64.6( \pm 9.4) \text { years } \\
\text { Control group: } \mathrm{n}=359 ; \\
65.6( \pm 9.5) \text { years } \\
\text { CAD } \\
\text { intervention group: } \mathrm{n}=172 ; 65.4 \\
( \pm 9.4) \text { years } \\
\text { Control group: } \mathrm{n}=97 ; \\
66.0( \pm 8.6) \text { years } \\
\text { CHF } \\
\text { intervention group: } \mathrm{n}=92 ; 67.3 \\
( \pm 7.9) \text { years } \\
\text { Control group: } \mathrm{n}=45 ; \\
62.4 \text { ( } \pm 7.7) \text { years } \\
\text { Telephone coaching }\end{array}$ & $\begin{array}{l}\text { Intervention: } 12 \text { months. } \\
\text { To evaluate the health effect } \\
\text { of } \mathrm{C} \text { on clinical outcomes (risk } \\
\text { determinants) in three patient } \\
\text { groups: CHF, CAD and DM } 2 .\end{array}$ & $\begin{array}{l}\text { Article removed from } \\
\text { review as included } \\
\text { participants aged } \\
\text { younger than } 60 \text { years. }\end{array}$ \\
\hline $\begin{array}{l}\text { Sahlen et al., 2013, } \\
\text { Sweden }^{13}\end{array}$ & $\begin{array}{l}\mathrm{N}=1.509 \\
\text { Intervention group: } \mathrm{n}=1,132 \\
\text { Control group: } \mathrm{n}=377 \\
\text { Age between } 60 \text { and } 75 \text { years } \\
\text { Coaching in person and by } \\
\text { telephone }\end{array}$ & $\begin{array}{l}\text { Intervention: } 18 \text { months. } \\
\text { Assess whether health C, } \\
\text { in terms of motivational } \\
\text { interviewing and a range of } \\
\text { activities, will contribute to } \\
\text { positive lifestyle and health } \\
\text { changes among older people at } \\
\text { risk for cardiovascular disease, } \\
\text { diabetes or mild depression. }\end{array}$ & $\begin{array}{l}\text { Article removed from } \\
\text { review as described } \\
\text { in progress or future } \\
\text { research protocol. }\end{array}$ \\
\hline $\begin{array}{l}\text { van Nimwegen et al., } \\
\text { 2013, Netherlands }{ }^{14}\end{array}$ & $\begin{array}{l}\text { Intervention group: } n=299 \text {; } \\
65.1( \pm 7.9) \text { years } \\
\text { Control group: } n=287 \\
65.9( \pm 7.2) \text { years } \\
\text { Face to face coaching }\end{array}$ & $\begin{array}{l}\text { Intervention: } 24 \text { months. } \\
\text { To evaluate whether a } \\
\text { multifaceted behavioral change } \\
\text { program (ParkFit specifically } \\
\text { designed to achieve a lasting } \\
\text { increase in physical activity } \\
\text { levels, with coaches using } \\
\text { motivational strategies) increases } \\
\text { physical activity in sedentary } \\
\text { Parkinson's disease patients. }\end{array}$ & $\begin{array}{l}\text { Article removed from } \\
\text { review as included } \\
\text { participants aged } \\
\text { younger than } 60 \text { years. }\end{array}$ \\
\hline
\end{tabular}


Continuation of Chart

\begin{tabular}{|c|c|c|c|}
\hline $\begin{array}{l}\text { Author, year, country } \\
\text { of publication }\end{array}$ & $\begin{array}{l}\text { Number of participants, age } \\
\text { group, delivery method }\end{array}$ & Intervention period, objectives & Exclusion, reason \\
\hline $\begin{array}{l}\text { Veroff et al., 2013, } \\
\text { USA }^{15}\end{array}$ & $\begin{array}{l}\mathrm{N}=24,167 \\
\text { Intervention group: } \mathrm{n}=13,901 \\
\text { Control group: } \mathrm{n}=10,266 \\
\text { Average age } \geq 49 \text { years } \\
\text { Telephone coaching }\end{array}$ & $\begin{array}{l}\text { Intervention: six months. } \\
\text { To assess IVR, which included } \\
\text { the ability of individuals at high } \\
\text { risk for spinal and knee surgery } \\
\text { to connect directly with the } \\
\text { Health Coach (AutoDialogW) } \\
\text { compared to a Control group. }\end{array}$ & $\begin{array}{l}\text { Article removed from } \\
\text { review as included } \\
\text { participants aged } \\
\text { younger than } 60 \text { years. }\end{array}$ \\
\hline $\begin{array}{l}\text { Tabak et al., 2014, } \\
\text { Netherlands }^{16}\end{array}$ & $\begin{array}{l}\text { Intervention group: } \mathrm{n}=15 \\
64.1( \pm 9.0) \text { years } \\
\text { Control group: } \mathrm{n}=14 ; \\
62.8( \pm 7.4) \text { years } \\
\text { Online coaching }\end{array}$ & $\begin{array}{l}\text { Intervention: nine months. } \\
\text { Evaluate a technology- } \\
\text { supported care program that } \\
\text { supports the treatment of } \\
\text { COPD patients through self- } \\
\text { treatment and promotion of an } \\
\text { active lifestyle through real-time } \\
\text { C and home exercise using a } \\
\text { web portal. }\end{array}$ & $\begin{array}{l}\text { Article removed from } \\
\text { review as included } \\
\text { participants aged } \\
\text { younger than } 60 \text { years. }\end{array}$ \\
\hline $\begin{array}{l}\text { Clare et al., 2015, } \\
\text { UK }^{17}\end{array}$ & $\begin{array}{l}\text { Intervention group: } \mathrm{n}=24 \\
\text { Control group: } \mathrm{n}=24 \\
\text { Average age } \geq 65 \text { years } \\
\text { Face to face and telephone } \\
\text { coaching }\end{array}$ & $\begin{array}{l}\text { Intervention: } 12 \text { months. } \\
\text { Evaluate a goal-setting } \\
\text { intervention aimed at promoting } \\
\text { cognitive enhancement, physical } \\
\text { activity, improving mental and } \\
\text { physical fitness, diet and health. }\end{array}$ & $\begin{array}{l}\text { Article removed as } \\
\text { did not consider the } \\
\text { objectives of the review } \\
\text { in their entirety. }\end{array}$ \\
\hline $\begin{array}{l}\text { Karhula et al., 2015, } \\
\text { Finland }^{18}\end{array}$ & $\begin{array}{l}\text { Cardiac patients: } n=246 ; 69.1 \\
( \pm 9.1) \text { years } \\
\text { Diabetes patients: } n=225 ; 66.2 \\
( \pm 8.6) \text { years } \\
\text { Telephone coaching }\end{array}$ & $\begin{array}{l}\text { Intervention: } 12 \text { months. } \\
\text { To evaluate whether a cell } \\
\text { phone based health } C \text { program } \\
\text { could be used to improve the } \\
\text { health-related quality of life of } \\
\text { patients with type } 2 \text { diabetes } \\
\text { and heart disease patients. }\end{array}$ & $\begin{array}{l}\text { Article removed from } \\
\text { review as included } \\
\text { participants aged } \\
\text { younger than } 60 \text { years. }\end{array}$ \\
\hline $\begin{array}{l}\text { Pavel et al., 2015, } \\
\text { USA }^{19}\end{array}$ & $\begin{array}{l}\mathrm{N}=33 \text { elderly persons; } 80.3 \\
( \pm 9.4) \text { years } \\
\text { Face to face and online } \\
\text { coaching }\end{array}$ & $\begin{array}{l}\text { Describe the structure of the } \\
\text { Health } C \text { platform prototype } \\
\text { and address aspects of the } \\
\text { components needed to support } \\
\text { its functions. }\end{array}$ & $\begin{array}{l}\text { Article removed as } \\
\text { did not consider the } \\
\text { objectives of the review } \\
\text { in their entirety. }\end{array}$ \\
\hline $\begin{array}{l}\text { Tiedemann et al., } \\
\text { 2015, Australia }\end{array}$ & $\begin{array}{l}\text { Intervention group: } n=65 \\
\text { Control group: } n=65 \text { patients } \\
\geq 60 \text { years } \\
\text { Face to face, internet and } \\
\text { telephone coaching }\end{array}$ & $\begin{array}{l}\text { Intervention: } 12 \text { months. } \\
\mathrm{C} \text { in health that aims to evaluate } \\
\text { personalized physical activity } \\
\text { and fall prevention intervention } \\
\text { in the elderly. }\end{array}$ & $\begin{array}{l}\text { Article removed from } \\
\text { review as described } \\
\text { in progress or future } \\
\text { research protocol. }\end{array}$ \\
\hline $\begin{array}{l}\text { Young et al., 2015, } \\
\text { USA }^{21}\end{array}$ & $\begin{array}{l}\mathrm{N}=15 \\
28 \text { to } 74 \text { years } \\
\text { Face to face coaching }\end{array}$ & $\begin{array}{l}\text { Intervention: three months. } \\
\text { Examine the feasibility and } \\
\text { effectiveness of a student- } \\
\text { oriented wellness program for } \\
\text { people with disabilities. }\end{array}$ & $\begin{array}{l}\text { Article removed from } \\
\text { review as included } \\
\text { participants aged } \\
\text { younger than } 60 \text { years. }\end{array}$ \\
\hline
\end{tabular}


Continuation of Chart

\begin{tabular}{|c|c|c|c|}
\hline $\begin{array}{l}\text { Author, year, country } \\
\text { of publication }\end{array}$ & $\begin{array}{l}\text { Number of participants, age } \\
\text { group, delivery method }\end{array}$ & Intervention period, objectives & Exclusion, reason \\
\hline $\begin{array}{l}\text { Cadmus-Bertram et } \\
\text { al., 2016, USA }\end{array}$ & $\begin{array}{l}\text { Intervention group: } \mathrm{n}=71 ; 60.0 \\
( \pm 6.3) \text { years } \\
\text { Control group: } \mathrm{n}=34 ; \\
60.8( \pm 6.2) \text { years } \\
\text { Telephone coaching }\end{array}$ & $\begin{array}{l}\text { Intervention: } 12 \text { months. } \\
\text { Evaluate an intervention that } \\
\text { trained women at high risk of } \\
\text { developing breast cancer to use } \\
\text { a self-monitoring and telephone } \\
\text { C site to increase physical } \\
\text { activity and lose weight. }\end{array}$ & $\begin{array}{l}\text { Article removed from } \\
\text { review as included } \\
\text { participants aged } \\
\text { younger than } 60 \text { years. }\end{array}$ \\
\hline$\frac{\text { Thomson et al., 2016, }}{\text { USA }^{22}}$ & $\begin{array}{l}\mathrm{N}=1.070 \\
\text { Average age } \geq 21 \text { years } \\
\text { Telephone coaching }\end{array}$ & $\begin{array}{l}\text { Intervention: } 24 \text { months. } \\
\text { To evaluate the hypothesis } \\
\text { that a } 24 \text {-month lifestyle } \\
\text { intervention will significantly } \\
\text { increase progression-free } \\
\text { survival following cancer } \\
\text { therapy for stage II-IV ovarian } \\
\text { cancer. }\end{array}$ & $\begin{array}{l}\text { Article removed from } \\
\text { review as described } \\
\text { in progress or future } \\
\text { research protocol. }\end{array}$ \\
\hline $\begin{array}{l}\text { Tiedemann, et al., } \\
\text { 2016, Australia }\end{array}$ & $\begin{array}{l}\mathrm{N}=600 \text { (60 Groups) } \\
\text { Physical activity and fall } \\
\text { prevention intervention } \\
\text { (30 Groups) } \\
\text { Healthy diet intervention } \\
\text { (30 Groups) } \\
\text { Individuals aged } \geq 60 \text { years } \\
\text { Telephone coaching }\end{array}$ & $\begin{array}{l}\text { Intervention: } 12 \text { months. } \\
\text { The main objective of this } \\
\text { study was to evaluate the effect } \\
\text { of an intervention for the } \\
\text { promotion of physical activity } \\
\text { combined with the prevention } \\
\text { of objectively measured and } \\
\text { self-reported falls compared } \\
\text { with dietary programs } \\
\text { among established groups of } \\
\text { community-dwelling people } \geq \\
60 \text { years of age. }\end{array}$ & $\begin{array}{l}\text { Article removed from } \\
\text { review as described } \\
\text { in progress or future } \\
\text { research protocol. }\end{array}$ \\
\hline $\begin{array}{l}\text { Early et al., 2017, } \\
\text { England }^{24}\end{array}$ & $\begin{array}{l}\text { Group } 1-\text { more advanced } \\
\text { COPD } \\
\text { Intervention group: } n=11 ; 66.36 \\
( \pm 12.33) \text { years } \\
\text { Group } 2 \text { - less advanced COPD } \\
\text { Intervention group: } n=8 ; 60.63 \\
( \pm 9.47) \text { years } \\
\text { Face to face. internet and phone } \\
\text { coaching }\end{array}$ & $\begin{array}{l}\text { Intervention: three months. } \\
\text { Evaluate the feasibility of an } \\
\text { internet-based health promotion } \\
\text { program, the Preventive Plan } \\
\text { (TPP), along with nursing } \\
\text { coaching for home-based } \\
\text { COPD self-management } \\
\text { focusing on patient activation } \\
\text { and self-management benefits. }\end{array}$ & $\begin{array}{l}\text { Article removed from } \\
\text { review as included } \\
\text { participants aged } \\
\text { younger than } 60 \text { years. }\end{array}$ \\
\hline $\begin{array}{l}\text { Vanroy et al., 2017, } \\
\text { Belgium }^{25}\end{array}$ & $\begin{array}{l}\text { Intervention group: } \mathrm{n}=25 ; 65.3 \\
( \pm 8.1) \text { years } \\
\text { Control group: } \mathrm{n}=21 ; \\
59.4( \pm 8.2) \text { years } \\
\text { Face to face coaching }\end{array}$ & $\begin{array}{l}\text { Intervention: six months. } \\
\text { To evaluate the short- and } \\
\text { long-term health and behavior- } \\
\text { related effects of a physical } \\
\text { activity intervention support } \\
\text { program in type } 2 \text { diabetes } \\
\text { mellitus patients. }\end{array}$ & $\begin{array}{l}\text { Article removed from } \\
\text { review as included } \\
\text { participants aged } \\
\text { younger than } 60 \text { years. }\end{array}$ \\
\hline $\begin{array}{l}\text { Rich et al., 2018, } \\
\text { USA }^{26}\end{array}$ & $\begin{array}{l}\mathrm{N}=408 \\
\text { Age } \geq 50 \text { years } \\
\text { Face to face coaching }\end{array}$ & $\begin{array}{l}\text { Intervention: } 24 \text { months. } \\
\text { Describe the intervention } \\
\text { protocol and study design } \\
\text { for the Peer Empowerment } \\
\text { Program } 4 \text { Physical Activity } \\
\text { (PEP4PA, coaching)). }\end{array}$ & $\begin{array}{l}\text { Article removed from } \\
\text { review as described } \\
\text { in progress or future } \\
\text { research protocol. }\end{array}$ \\
\hline
\end{tabular}

C: coaching; CHF: congestive heart failure; CAD: coronary artery disease; DM2: type 2 diabetes mellitus; COPD: chronic obstructive pulmonary disease; IVR: interactive voice response. 
Chart 2. Description of articles selected and included in the review. Maringá, Paraná, 2018.

\begin{tabular}{|c|c|c|c|c|}
\hline $\begin{array}{l}\text { Author, } \\
\text { year and } \\
\text { country of } \\
\text { publication }\end{array}$ & $\begin{array}{l}\text { Number of participants, } \\
\text { age group, delivery } \\
\text { method }\end{array}$ & $\begin{array}{l}\text { Intervention period, } \\
\text { objectives }\end{array}$ & Coaching tool & Results \\
\hline $\begin{array}{l}\text { Broekhuizen } \\
\text { et al., 2016, } \\
\text { Netherlands }^{6}\end{array}$ & $\begin{array}{l}\text { Controlled and } \\
\text { randomized control } \\
\text { study } \\
\mathrm{N}=235 \\
\text { Intervention group: } \mathrm{n}= \\
119 ; 64.7 \text { ( } \pm 3.0) \text { years } \\
\text { Control group: } \mathrm{n}=116 ; \\
64.9 \text { ( } \pm 2.8) \text { years } \\
\text { T-test for independent } \\
\text { samples. Mann-Whitney } \\
\text { and linear regression } \\
\text { tests } \\
\\
\text { Online coaching }\end{array}$ & $\begin{array}{l}\text { Intervention: three } \\
\text { months. } \\
\text { Evaluate an } \\
\text { intervention based } \\
\text { on a physical activity } \\
\text { program available on } \\
\text { the internet, DirectLife } \\
\text { (C program), aimed } \\
\text { at increasing physical } \\
\text { activity to improve } \\
\text { the quality of life of } \\
\text { inactive older adults. }\end{array}$ & $\begin{array}{l}\text { Program with a } \\
\text { personal coach, which } \\
\text { provides regular email } \\
\text { updates of physical } \\
\text { activity and advice on } \\
\text { how to increase such } \\
\text { activity. }\end{array}$ & $\begin{array}{l}\text { The use of the physical } \\
\text { activity program } \\
\text { available on the } \\
\text { internet, DirectLife (C } \\
\text { program), significantly } \\
\text { improved quality of } \\
\text { life, especially the } \\
\text { emotional health of } \\
\text { older participants in } \\
\text { the Intervention group } \\
\text { compared to older } \\
\text { adults in the Control } \\
\text { group. }\end{array}$ \\
\hline $\begin{array}{l}\text { Park et al., } \\
\text { 2017, South } \\
\text { Korea }^{7}\end{array}$ & $\begin{array}{l}\text { Controlled and } \\
\text { randomized trial } \\
\mathrm{N}=90 \\
\text { Intervention group: } \mathrm{n}= \\
43 ; 80.91 \text { ( } \pm 7.65) \text { years } \\
\text { Control group: } \mathrm{n}=47 ; \\
80.19 \text { ( } \pm 7.53) \text { years } \\
\text { T test. Chi-squared and } \\
\text { ANOVA } \\
\text { Face to face coaching }\end{array}$ & $\begin{array}{l}\text { Intervention: two } \\
\text { months. } \\
\text { To evaluate the effect of } \\
\text { a self-management and } \\
\text { C in health (HCSMP- } \\
\text { NHR) program } \\
\text { designed for older } \\
\text { people with chronic } \\
\text { conditions and mild } \\
\text { to moderate cognitive } \\
\text { impairment living in } \\
\text { nursing homes. }\end{array}$ & Goal-based counselling. & $\begin{array}{l}\text { HCSMP-NHR } \\
\text { improved the self- } \\
\text { efficacy, achievement } \\
\text { of goals, health status } \\
\text { and quality of life } \\
\text { of older people with } \\
\text { chronic conditions } \\
\text { and mild to moderate } \\
\text { cognitive impairment. }\end{array}$ \\
\hline $\begin{array}{l}\text { Zimmerman } \\
\text { et al., } 2017 \text {, } \\
\mathrm{USA}^{27}\end{array}$ & $\begin{array}{l}\text { Randomized control } \\
\text { study } \\
\mathrm{N}=18,107 \\
\geq 65 \text { years, with average } \\
\text { age of } 74.2 \text { years } \\
25 \text { primary care clinics } \\
\text { stratified by city, } \\
\text { Pittsburgh } \\
\mathrm{n}=19 \text { clinics and } \\
\text { Houston } \mathrm{n}=6 \text { clinics } \\
\text { Chi-squared and } \\
\text { Hazard ratio } \\
\\
\text { Face to face and } \\
\text { telephone coaching }\end{array}$ & $\begin{array}{l}\text { Intervention: } 24 \\
\text { months. } \\
\text { To evaluate the } \\
\text { effectiveness of } \\
\text { an evidence-based } \\
\text { guide, the } 4 \text { Pillars } \\
\text { TM Immunization } \\
\text { Toolkit (education } \\
\text { and coaching), to } \\
\text { increase pneumococcal } \\
\text { vaccination in the } \\
\text { elderly. }\end{array}$ & $\begin{array}{l}\text { Face to face } C \\
\text { advocating the } \\
\text { importance of } \\
\text { immunization for the } \\
\text { team. } \\
\text { Phone } C \text { to ensure } \\
\text { that the chosen } \\
\text { strategies were being } \\
\text { implemented and } \\
\text { to work with team } \\
\text { motivation. }\end{array}$ & $\begin{array}{l}\text { Intervention and } \\
\text { control groups } \\
\text { increased PPSV } \\
\text { vaccination rates in } \\
\text { in the elderly. In the } \\
\text { pre and post study, } \\
\text { the use of the } 4 \text { Pillars } \\
\text { TM Immunization Kit } \\
\text { significantly improved } \\
\text { vaccination with PPSV } \\
\text { and PCV compared } \\
\text { to practices in the } \\
\text { maintenance phase of } \\
\text { the study. }\end{array}$ \\
\hline
\end{tabular}

PPSV: 23-valent polysaccharide pneumococcal vaccine; PCV: pneumococcal conjugate vaccine; C: coaching. 
Of the three articles selected, two applied face to face coaching ${ }^{7,27}$, one of which combined face to face coaching with telephone coaching ${ }^{27}$, and one article applied only online coaching ${ }^{6}$. The intervention period ranged from two to 24 months. In terms of objectives, the studies sought to evaluate coaching tools for lifestyle changes and health risk reduction.

The results achieved in the studies were positive, with a significant improvement in quality of life (mental and physical) ${ }^{6,7}$; health status ${ }^{7}$; achieving goals $^{7}$; self-efficacy ${ }^{7}$ and increased immunization ${ }^{27}$ of the elderly persons evaluated.

\section{DISCUSSION}

There are few articles that evaluate the effect of coaching on health promotion, hampering a robust analysis of the effect of coaching on health promotion among the elderly. Most studies analyzed in their entirety $(n=21)$ at the eligibility stage were excluded $(n=10)$ as they included older and middle-aged individuals in the groups evaluated (intervention and control), which may mean the results are unreliable, as the elderly have their own characteristics resulting from the aging process. In addition, six studies were from future or ongoing study protocols.

It was also observed that although the studies reported the use of coaching for health promotion, there is great difficulty on the part of the authors when it comes to understanding the term "health coaching". In general, the understanding of coaching observed was focused on the action of a health professional who combines information and health education to encourage the individual to initiate and maintain behavioral changes associated with health. This procedure, however, relates to the application of mentoring rather than coaching. The former involves the transmission of instructions from an individual who has knowledge of a specific domain to a less experienced individual, and does not require mentor coaching skills ${ }^{28}$. Coaching, on the other hand, is a process in which the coach (the one who leads the process) facilitates the learning of an individual without, however, having knowledge of the area of learning of such individual, that is, the coach only needs to have experience in the process of learning facilitation and performance enhancement ${ }^{29}$. Coaching is a process of human development that involves the use of structured, focused interactions and strategies, as well as appropriate tools and techniques to bring about desirable change for the benefit of the individual. ${ }^{30}$

The lack of understanding and inadequate use of these techniques may be related to the scarcity in literature of information about the specifications needed for coach training. There are some basic requirements for working in this area, such as: obtaining a coaching development training certificate; have gone through a specific coaching process; have carried out work on one's own; provide adequate vocational training; remain under constant supervision in one's activities as a coach ${ }^{29}$. Other limitations of health coaching studies are associated with the lack of clarification about the characteristics of health coaching (strategies, practices, delivery methods); what is the exact role of the coach (educator, facilitator, navigator, partner); what training is required to act as a coach and what type of training would enable such professionals to perform competently in the health coaching process ${ }^{31}$.

The difficulty in defining the coach's duties, as well as their academic training or the training methodology verified in the studies, made selection difficult and restricted the results to a few articles. It was a challenging task, given the variety of concepts used, the diversity of approaches, as well as the scarcity of studies focused on the theme.

The evidence of the selected articles ${ }^{6,7,27}$ in the present review that met the eligibility criteria suggests that coaching is a viable strategy for improving health, self-management, adherence to health promotion activities and, consequently, to improving the quality of life of the elderly. Programs that enable the elderly to self-manage their symptoms and treatments based on lifestyle changes are essential for a healthy life $^{32}$. Self-management improves problem solving, the maintenance of exercise, medication use, and communication skills. ${ }^{33}$

The coaching methodology presents beneficial results that lead to behavioral and lifestyle changes, such as increased physical activity, improved nutrition 
and self-esteem ${ }^{34-36}$, reinforcing that this technique can be used as a strategy for health promotion, aimed at such promotion and an improved quality of life.

Thus, research evaluating the effects of coaching on health promotion in the elderly needs to be further explored, as the world's older population is expanding rapidly. This is a challenge for the health care needs of these individuals, as aging is a multifactorial process that promotes anatomical and functional changes in the body. Such changes usually result in the onset of chronic diseases; functional disability; the need for care; reduced mobility; depression; isolation and loneliness, which can negatively influence the quality of life of the older adult ${ }^{37}$.

Under chronic conditions, the commitment to self-care and the ability to adhere to long-term recommendations is of utmost importance. In this sense, health coaching motivates individuals to initiate and maintain change, and to recognize factors that contribute to achieving their goals ${ }^{4}$. Health coaching is an effective strategy for older people to prevent a disease from getting worse and for improving their lifestyle ${ }^{38}$.

Limitations of the present study include its design, as the eligibility criterion meant that only free full text studies in the searched databases were evaluated, the sample size obtained (three articles) and the individualistic approach, as observed in one of the selected studies, in which the participation of the older adults was voluntary, which may have contributed to the representation of participants who were highly motivated towards lifestyle-related changes. Similarly, the restricted selection of internetenabled elderly persons led to a sample with a relatively high educational level; as a consequence, the application of the results of this study to the general elderly population is limited $^{6}$.

\section{CONCLUSION}

Although the studies produced promising results, suggesting that health coaching brings about changes in the disease management and lifestyle of the elderly, the application of the methodology in health promotion for older individuals is still incipient. The sense of partnership between patients and health professionals promoted through the coaching methodology, either face to face, online or by phone, can be a tool used to promote the health of the elderly.

The importance of further studies that evaluate the coaching methodology in the health promotion of elderly persons in the areas involved, such as those related to physical, mental and social aspects, is emphasized. Such studies are important for the planning of strategies that aim to implement actions for the promotion of the health of the elderly, contributing to geriatric and gerontological research and practice.

Edited by: Ana Carolina Lima Cavaletti

\section{REFERENCES}

1. Barosa Pereira A. Coaching em Portugal: Teoria e Prática. Lisboa: Edições Sílabo; 2008.

2. Ustá V. Coaching na gestão de enfermagem [Dissertação]. Lisboa: Escola Superior de Enfermagem de Lisboa, Curso de Mestrado em Enfermagem; 2012.

3. Linden A, Butterworth SW, Prochaska JO. Motivational interwiewing-based health coaching as a cronic care intervantion. J Eval Clin Pract. 2010;16(1):166-74.

4. Wolever RQ, Dreusicke M, Fikkan J, Hawkins TV, Yeung S, Wakefield J, et al. Integrative health coaching for patients with type 2 diabetes: a randomized clinical trial. Diabetes Educ. 2010;36(4):629-39.
5. Cadmus-Bertram L, Nelson SH, Hartman S, Patterson RE, Parker BA, Pierce JP. Randomized trial of a phone and web based weight loss program for women at elevated breast cancer risk: the HELP study. J Behav Med. 2016;39(4):551-9.

6. Broekhuizen K, de Gelder J, Wijsman CA, Wijsman LW, Westendorp RG, Verhagen E, et al. An Internet based physical acivity intervention to improve quality of life of inactive older adults: a randomized controlled trial. J Med Internet Res [Internet]. 2016 [acesso em 06 jul. 2018];18(4):e74 [16p.]. Disponível em: https://www.ncbi.nlm.nih.gov/ pmc/articles/PMC4917725/ 
7. Park YH, Moon SH, Ha JY, Lee MH. The longterm effects of the health coaching selfmanagement program for nursing-homeresidents. Clin Interv Aging 2017;11:1079-88.

8. Fundo de População das Nações Unidas. Envelhecimento no século XXI: celebração e desafio: resumo executivo. Nova York: UNFPA; 2012.

9. Galvão TF, Pansani TSA, Harrad D. Principais itens para relatar Revisões sistemáticas e Metaanálises: a recomendação PRISMA. Epidemiol Serv Saúde. 2015;24(2):335-42.

10. Clark PG, Blissmer BJ, Greene GW, Lees FD, Riebe DA, Stamm KE. Maintaining exercise and healthful eating in older adults: the SENIOR project II: study design and methodology. Contemp Clin Trials. 2011;32(1):129-39.

11. Long JA, Jahnle EC, Richardson DM, Loewenstein G, Volpp KG. Peer mentoring and financial incentives to improve glucose control in African American veterans: a randomized trial. Ann Intern Med. 2012;156(6):416-24.

12. Patja K, Absetz P, Auvinen A, Tokola K, Kytö J, Oksman E, et al. Health coaching by telephony to support self-care in chronic diseases: clinical outcomes from The TERVA randomized controlled trial. BMC Health Serv Res [Internet]. 2012 [acesso em 08 jul. 2018];12:1-8. Disponível em: https:// www.ncbi.nlm.nih.gov/pmc/articles/PMC3502505/ pdf/1472-6963-12-147.pdf

13. Sahlen KG, Johansson H, Nyström L, Lindholm L. Health coaching to promote healthier lifestyle among older people at moderate risk for cardiovascular diseases, diabetes and depression: a study protocol for a randomized controlled trial in Sweden. BMC Public Health [Internet]. 2013 [acesso em 08 jul. 2018];13:19. Disponível em: https://www.ncbi.nlm.nih.gov/ pmc/articles/PMC3599987/pdf/1471-2458-13-199.pdf

14. van Nimwegen M, Speelman AD, Overeem S, van de Warrenburg BP, Smulders K, Dontje ML, et al. Promotion of physical activity and fitness in sedentary patients with Parkinson's disease: randomised controlled trial. BMJ [Internet]. 2013 [acesso em 08 jul. 2018];346:1-16. Disponível em: https://www.ncbi. nlm.nih.gov/pmc/articles/PMC3585777/

15. Veroff DR, Ochoa-Arvelo T, Venator B. A randomized study of telephonic care support in populations at risk for musculoskeletal preferencesensitive surgeries. BMC Med Inform Decis Mak [Internet]. 2013 [acesso em 08 jul. 2018];13:1-18. Disponível em: https://www.ncbi.nlm.nih.gov/pmc/ articles/PMC3575312/
16. Tabak M, Brusse-Keizer M, van der Valk P, Hermens $\mathrm{H}$, Vollenbroek-Hutten M. A telehealth program for self-management of COPD exacerbations and promotion of an active lifestyle: a pilot randomized controlled trial. Int J Chronic Obstruct Pulmon Dis. 2014;9:935-44.

17. Clare L, Nelis SM, Jones IR, Hindle JV, Thom JM, Nixon JA, et al. The Agewell trial: a pilot randomised controlled trial of a behaviour change intervention to promote healthy ageing and reduce risk of dementia in later life. BMC Psychiatry [Internet]. 2015 [acesso em 08 jul. 2018];15:1-28. Disponível em: https://www. ncbi.nlm.nih.gov/pmc/articles/PMC4337106/

18. Karhula T, Vuorinen AL, Rääpysjärvi K, Pakanen M, Itkonen P, Tepponen M, et al. Telemonitoring and Mobile Phone-Based Health Coaching Among Finnish Diabetic and Heart Disease Patients: randomized controlled trial. J Med Internet Res [Internet]. 2015 [acesso em 08 jul. 2018];17(6):e153 [20 p.]. Disponível em: https://www.ncbi.nlm.nih.gov/ pmc/articles/PMC4526947/

19. Pavel M, Jimison HB, Korhonen I, Gordon CM, Saranummi N. Behavioral Informatics and Computational Modeling in Support of Proactive Health Management and Care. IEEE Trans Biomed Eng. 2015;62(12):2763-75.

20. Tiedemann A, Paul S, Ramsay E, O’Rourke SD, Chamberlain K, Kirkham C, et al. What is the effect of a combined physical activity and fall prevention intervention enhanced with health coaching and pedometers on older adults' physical activity levels and mobility-related goals?: Study protocol for a randomised controlled trial. BMC Public Health [Internet]. 2015 [acesso em 08 jul. 2018];15:1-10. Disponível em: https://www.ncbi.nlm.nih.gov/pmc/ articles/PMC4429838/

21. Young HJ, Erickson ML, Johnson KB, Johnson MA, McCully KK. A wellness program for individuals with disabilities: Using a student wellness coach approach. Disabil Health J. 2015;8(3):345-52

22. Thomson CA, Crane TE, Miller A, Garcia DO, Basen-Engquist K, Alberts DS. A randomized trial of diet and physical activity in women treated for stage II-IV ovarian cancer: Rationale and design of the Lifestyle Intervention for Ovarian Cancer Enhanced Survival (LIVES): An NRG Oncology/Gynecologic Oncology Group (GOG-225) Study. Contemp Clin Trials. 2016;49:181-9. 
23. Tiedemann A, Rissel C, Howard K, Tong A, Merom D, Smith S, et al. Health coaching and pedometers to enhance physical activity and prevent falls in community-dwelling people aged 60 years and over: study protocol for the Coaching for Healthy AGEing (CHAnGE) cluster randomised controlled trial. BMJ Open [Internet]. 2016 [acesso em 09 jul. 2018];6(5):e012277 [14]. Disponível em: https://www. ncbi.nlm.nih.gov/pmc/articles/PMC4874201/

24. Early F, Young JS, Robinshaw E, Mi EZ, Mi EZ, Fuld JP. A case series of an off-the-shelf online health resource with integrated nurse coaching to support self-management in COPD. Int J Chronic Obstr Pulmon Dis. 2017;12:2955-67.

25. Vanroy J, Seghers J, Bogaerts A, Devloo K, De Cock $\mathrm{S}$, Boen F. Short- and long-term effects of a needsupportive physical activity intervention among patients with type 2 diabetes mellitus: A randomized controlled pilot trial. PLoS One [Internet]. 2017 [acesso em 09 jul. 2018];12(4):e0174805 [16p.]. Disponível em: https://www.ncbi.nlm.nih.gov/pmc/ articles/PMC5383224/

26. Rich P, Aarons GA, Takemoto M, Cardenas V, Crist $\mathrm{K}$, Bolling $\mathrm{K}$, et al. Implementation-effectiveness trial of an ecological intervention for physical activity in ethnically diverse low income senior centers. BMC Public Health [Internet]. 2017 [acesso em 8 jul. 2018];18(1):29. Disponível em: https://www.ncbi.nlm. nih.gov/pmc/articles/PMC5516364/

27. Zimmerman RK, Brown AE, Pavlik VN, Moehling KK, Raviotta JM, Lin CJ, et al. Using the 4 Pillars Practice Transformation Program to Increase Pneumococcal Immunizations for Older Adults: a Cluster-Randomized Trial. J Am Geriatr Soc. 2017;65(1):114-22.

28. Grant AM. Towards a psychology of coaching: The impact of coaching on metacognition, mental health and goal attainment [Doctoral thesis]. Australia: Macquarie University, Departament of Psychology; 2001.
29. Oliveira-Silva LC, Werneck-Leite CDS, Carvalho PSF, Anjos AC, Brandão HIM. Desvendando o Coaching: uma Revisão sob a Ótica da Psicologia. Psicol Ciênc Prof. 2018;38(2):363-77.

30. Cox E, Bachkirova T, Clutterbuck D. The complete handbook of coaching. London: Sage; 2014.

31. Wolever RQ. Health \& Wellness Coaching: evidence, challenges and opportunities. London: Vanderbilt University Medical Center; 2016.

32. Richard AA, Shea K. Delineation of self-care and associated concepts. J Nurs Scholarsh. 2011;43(3):255-64.

33. Jordan JE, Briggs AM, Brand CA, Osborne RH. Enhancing patient engagement in chronic disease self-management support initiatives in Australia: the need for an integrated approach. Med J Aust. 2008;189(10 Suppl):9-13.

34. Mendes FP, Garin NC, Timm EZ, Ribeiro J L. Aplicação da metodologia coaching para o tratamento da obesidade: uma visão multidisciplinar. Ciênc Mov. 2017;19(39):61-9.

35. Magalhães T, Neves L, Poínhos R. A metodologia de coaching aplicada às ciências da nutrição: usos, potencialidades e controvérsias em Portugal. Acta Port Nut. 2018;12:26-31.

36. Meya-Molina A, Giménez-Sánchez J. Coaching nutricional como herramienta para la adquisición de hábitos alimentarios preventivos del cáncer. Rev Esp Nutr Hum Diet. 2014;18(1):35-44.

37. Ory MD, Cox DM. Forging ahead: Linking health and behavior to improve quality of life in older people. In: Romney DM, Brown RI, Fry PS, editors. Improving the Quality of Life. Dordrecht: Springer Publishing Company; 1994.

38. Huffman M. Health coaching: a new and exciting technique to enhance patient self-management and improve outcomes. Home Healthc Nurse. 2007;25(4):271-4. 